\title{
THE POLITICS OF PLUNDER: THE RHETORICS OF ORDER AND DISORDER IN SOUTHERN NIGERIA
}

\author{
Charles Gore \\ DAVID PRATTEN
}

\begin{abstract}
The paper looks at four cases of youth-led identity-based social movements in Benin city and in the Annang area of southern Nigeria. It shows how each of these movements youth associations, 'area boys', vigilantes and campus cults - draws on different, older repertoires of discourse and organisation, and enter into relations with state authority that combine elements of complicity, insurgency, monitoring and disengagement. It argues that their activities, mobilized around resource control and community security, can be understood as a response to the Nigerian 'politics of plunder', endemic since the beginning of the oil boom, but locally perceived as having intensified from the 1990s onwards.
\end{abstract}

President Obasanjo has staked a great deal on the politics of equity, order and accountability in Nigeria. As the former Chairman of the Advisory Council of a leading international corruption watch-dog, Transparency International, he has pledged to leave an enduring legacy of zero tolerance towards corruption in Nigeria. Consequently, there have been numerous official initiatives to reform the Nigerian political economy, including the Human Rights violations investigation Commission, Contracts and Appointments Review Panel, drafting of an Anti-Corruption bill, and public hearings on political probity which led to the impeachment of the Senate president in August 2000. Neither these high-profile steps, nor reforms in local policing and local government, however, have significantly affected the everyday and local experience of disorder. In contrast, popular responses to economic mismanagement, regional marginalisation and crime waves since the return to democracy have been prolific and controversial, especially in the emergence of youth-led identity-based social movements. Indeed, the widespread mobilization of youth in contemporary civil disorder provides a popular counter-narrative to the legitimacy of the Nigerian nation state.

The so-called 'ethnic militias', the Oodua People's Congress (OPC) in the West, the Ijaw Egbesu boys in the Niger Delta, the Bakassi Boys and the Movement of the Actualization of the Sovereign State of Biafra (MASSOB) in the East, and the Arewa People's Congress (APC) in the North spearhead contemporary political contests between the politics of identity and citizenship. These emergent collective groupings foreground contemporary social movements representing divergent imaginings of Nigeria: pro-Sharia in the north, ethnic nationalism in the west, and autonomous resource control in the oilproducing south. Underscored by ethnic chauvinism, and vigilantism against crime and 'moral degradation', the ethnic militias invoke the spectre of separatism and are perceived to 'threaten the all-Nigeria ideals of Obasanjo's elected government. ${ }^{1}$ While the potential

Charles Gore is a lecturer at the Open University David Pratten is a British Academy Post-doctoral Research Fellow at the School of Oriental and African Studies, University of London. We would both like to acknowledge the support of the British Academy to our research (grants APN-7026 and SG-32993). This paper was presented to several audiences including the African Studies Centre, Leiden, to the ASAUK 2002 conference held at the University of Birmingham, and to a workshop organized by the International Development Studies Centre, Roskilde University. We would like to thank John Peel and Axel Klein for their encouragement and the journal's referee and editors for their comments.

1. Africa Confidential, 27 October 2000. 
of such threats to national sovereignty may be exaggerated, the breadth and depth of the processes which have produced the ethnic militias is not. Violent local responses by youth groups mobilized around issues of resource control and community security are a widespread response to the 'politics of plunder', and an endemic feature of the Nigerian social landscape.

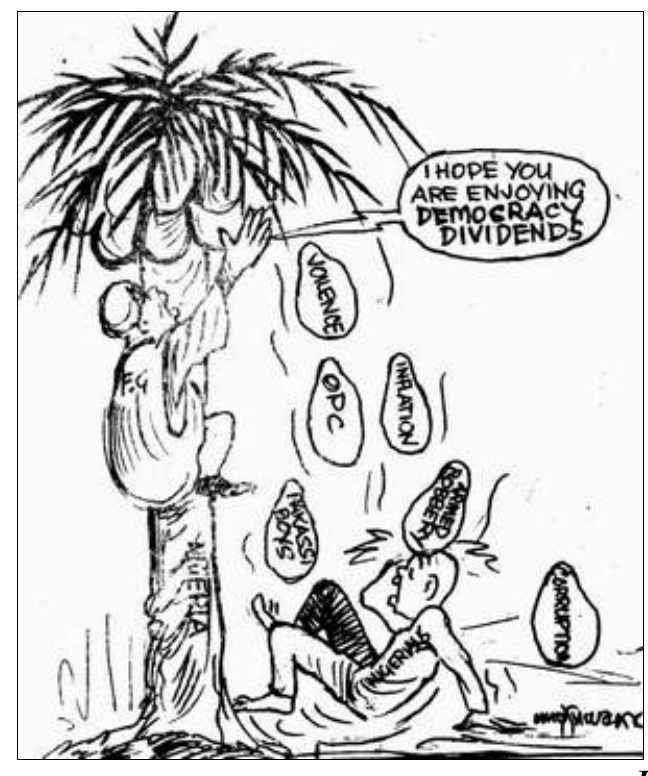

Pioneer, 10 September 2001

Nigeria's 'political economy of predation'2 is manifest in an apparent institutional monopoly of violence and rampant prebendalism which reflects the extractive nature of the state and the accumulative base of ethno-regional commercial and bureaucratic classes. ${ }^{3}$ Popular fears of a predatory state are not focused on a monolithic, bureaucratic structure, however, but are fears of a set of procedures through which personal power is exercised through state offices and processes in political conflict and competition. Indeed, routine relationships between state and society in Nigeria are currently dominated by discourses on the illegitimacy of instrumentalized distribution and disorder. It is this very illegitimacy which shapes individual and collective local responses. On one axis, the politics of distribution, people are organising themselves within familiar frameworks to 'capture' the state. On the other, discourses on disorder, law and order, social practices are mobilized as a response to and a protection against the state. In short, governance, the relationship between people and the state, is shaped by the opportunities afforded through the instrumentalisation of distribution and by necessity in the face of the insecurities of instrumentalized disorder. The rhetorics of order and disorder in this context constitute both discursive modes and bases for collective action.

Since 1999 and a return to multi-party democracy Nigeria has witnessed intensified contests concerning rights over economic re-distribution and judicial authority, and the privileges of representation and patrimony. It is therefore an especially relevant context in which to explore Mbembe's observation that what have hastily been referred to as 'transitions to democracy' in Africa are in fact ongoing struggles for the codification of

2. Jean-Francois Bayart 'Conclusion', in Jean-Francois Bayart, Stephen Ellis, and Beatrice Hibou (eds.), The Criminalization of the State in Africa, (James Currey, Oxford, 1999).

3. Olufemi Vaughan, 'Assessing Grassroots Politics and Community Development in Nigeria' African Affairs 94, (1995), p. 512. 
new rights and privileges. ${ }^{4}$ These struggles, combined with worsening inequalities and corruption, lead to public and private violence that is increasingly uncontrolled. The question as posed by Mbembe is the extent to which these contests challenge the state as a 'public good', as the instrument for ensuring protection and safety for individuals, as the arena for creating the legal conditions for the extension of political rights, and for making possible the exercise of citizenship. ${ }^{5}$ This article seeks to locate these contests in the cultural politics of accountability which are revealed in everyday practice. ${ }^{6}$ We argue that analysis of popular responses to disorder contributes to an 'insurgent' construction of the public realm in which groups marginalized and excluded challenge the logic, locations, patterns of discourse and constructions of the public good. ${ }^{7}$

In Nigeria many people participate in social activities outside the regulatory frameworks maintained by the state. They are constructively engaged in creating and engaging in social formations and associations that are often legitimated by longstanding traditions that lay claim (in principle if not in practice) to an autonomy from the state. The collective responses to disorder focused on here include youth associations, area boys, vigilantes, and cults. These forms of associational interaction take place within the context of localized religions and cultural frameworks with traditions (historical or invented) that precede the colonial enclosures. These are often dismissed as neo-traditional and reactionary. Chabal and Daloz, for example, observe a 're-traditionalisation' of African society visible in a resurgence of ethnicity and ritualized violence. ${ }^{8}$ Yet, historical precedents and their classification as neo-traditional often obscures the activities that take place within these associational forms and their interactions with the state and other forms of collective activity. Contrary to the premises of the re-traditionalisation thesis we argue the need to address histories of localized idioms of power, knowledge and accountability in understanding popular responses to the instrumentalisation of disorder. The engagement with the state through the use of localised idioms of accountability contributes to an ongoing creative reconfiguration and diversity of these discourses over time.

In the northern states of Nigeria grassroots responses to disorder are evident in youthled social movements which draw legitimacy from shared Islamic idioms. In Nigeria's southern states youth movements engage in the discourses on marginalisation, disorder and crime by drawing on idioms of particularistic community identity and on trajectories of generational and secret societies. In north and south, the so-called 'ethnic militias' and their localized variants contest power through complex and ambiguous conceptions of accountability which are played out in everyday politics within idioms of monitoring and surveillance, screening and vigilance. These repertoires of accountability operate, within a framework of implied or explicit violence and at various opportunistic nodes of redistribution. Hence, within these spheres youth groups have presented various responses including vigilantism, screening political candidates, monitoring local government expenditure, checking the award of compensation payments to local chiefs, threatening contractors and para-statals to complete development programmes, and monitoring price controls.

4. A. Mbembe, On the Postcolony (University of California, 2001), p. 68.

5. Mbembe, On the Postcolony, p. 73.

6. M. de Certeau, The Practice of Everyday Life (University of California Press, Berkeley, 1984).

7. Harry C. Boyte 'The Pragmatic Ends of Popular Politics', in Craig Calhoun (ed.), Habermas and the Public Sphere, (Massachusetts Institute of Technology, 1992), p. 341.

8. Patrick Chabal and Jean-Pascal Daloz, Africa Works: The Political Instrumentalization of Disorder (James Currey, London, 1999), p. 45. 
The relationships linking formal institutions of governance to society at large and to these youth movements in particular are likely to display an opaque and ambiguous quality. To speak of the 'space' in-between such institutions and society underplays the individual aspect of the personalization of power, and attempting to describe the very 'narrowness' of affiliations, kinship ties, dependencies and favours through which institutions and society are linked might conversely suggest the reverse: that there is daylight rather than 'twilight' between them. ${ }^{9}$ Mobilization through idioms and practices (youth, power and secrecy) which are themselves historically and politically ambiguous framings serves further to blur the boundaries of this relationship. Nevertheless, this ambivalent sometimes covert, sometimes subversive space is highlighted through the dialectical engagements (and disengagements) of individuals and collective groupings with the diverse and heterogeneous institutions of the Nigerian nation state. In this context the instability of its norms, laws and institutions, make it a privileged site for negotiation, bargaining and brokerage. ${ }^{10}$

In the late 1980s and 1990s in Nigeria, discourses on state and society have emerged from the self proclaimed politically marginalized - the 'youth' - which in contemporary Nigerian parlance has become a term of exclusion. Youth is a complex, fluid and permeable category which is historically and socially situated. As such it is a site for particular and localized framings of human agency constituted by various intersecting and contested discourses. Its salience as a theoretical category has been determined by its relation to particular models of social organisation incorporated within various theoretical paradigms. In these approaches youth has been portrayed as a transient, subordinate and deviant category. Within structural-functionalist models conflict subsumed within an intergenerational framing assumes that it is part of the reproduction of social organisation over time as cohorts pass from youth to elderhood, rendering conflict as an integral and situational component of the structures of social organisation which engender it. ${ }^{11}$ In Marxist analyses the hierarchy of age and the dominance of elders over youth in the village setting is articulated in relation to those precolonial categories through which resources are managed for the benefit of the community. ${ }^{12}$ And where the actions and agency of youth themselves have gained prominence with potential for radical social change, particularly in the fast developing urban conurbations of Africa, this has usually been framed as deviant and disruptive rather than as an important site and catalyst in varied processes of social change. ${ }^{13}$

It is necessary, therefore, to elucidate local understandings of youth and to determine in what kind of political space youth participate. ${ }^{14}$ Nigerian youths' claims of marginalization resonate within the sphere of 'high' politics. The dissemination of these discourses and

9. C. Lund, 'Precarious Democratization and Local Dynamics in Niger: Micro-Politics in Zinder' Development and Change 32, (2001).

10. J. P. Olivier de Sardan, 'A Moral Economy of Corruption in Africa?' The Journal of Modern African Studies 37, (1999), pp. 37-38.

11. Paul Spencer 'The Function of Ritual in the Socialization of the Samburu Moran', in Philip Mayer (ed.), Socialization: The Approach from Social Anthropology, (Tavistock, London, 1970).

12. C. Meillassoux "the Economy' in Agricultural Self-Sustaining Societies: A Preliminary Analysis', in D. Seddon (ed.), Relations of Production: Marxist Approaches to Social Anthropology, (Frank Cass, London, 1978).

13. J. S. La Fontaine 'Two Types of Youth Group in Kinshasa (Léopoldville)', in Philip Mayer (ed.), Socialization: The Approach from Social Anthropology, (Tavistock, London, 1970).

14. Deborah Durham, 'Youth and the Social Imagination in Africa: Introduction to Parts 1 and 2 ' Anthropological Quarterly 73, (2000). 
their appropriation by a range of protagonists is underlined by the way in which Governors of the Southern states have sought to challenge the national oil allocation to the various federal states. They have formed a grouping as the self-promoted 'young' politicians in order to form a common base for action to gain control of these oil revenues through the courts and informally through personal political networks. These Southern Governors (including Lucky Igbenedion of Edo state and Victor Attah of Akwa Ibom State) have aligned themselves as part of the youth category in order to engage with and hold accountable the nation state. ${ }^{15}$ Indeed, an intergenerational configuration maps onto perceptions of 'high' politics. Older politicians complain that President Babangida promoted a 'new breed' to enter politics when he banned former politicians from standing in the 1993 round of elections. ${ }^{16}$ The 'old guard' now complain that the excesses of economic mismanagement in subsequent years were inevitable as young men without personal assets enriched themselves from public coffers, and that they cannot, in local parlance, 'sanitize' contemporary politics since the organs of the public sphere, the press in particular, are controlled by the very people who are in power.

Nevertheless, this paper locates youth and their organisations within the 'deep', vertical politics of patrimonialism. ${ }^{17}$ As elsewhere on the continent, the category of youth has emerged since the watershed of economic reforms in the late 1980s and early 1990s as a key site in Nigerian political discourse. With the reduction in public sector employment opportunities and with personal networks of patronage 'squeezed', the category of youth which is locally conceptualized as relatively transitory in its parallels to the age set cohorts has crystallized into an extended social category in terms of its duration. A large population are situated in this context of 'extended youth' irrespective of actual age through economic and social circumstances and with little prospect of future advancement. Demographically, in $199628 \%$ of the Nigerian population was between the age of 10 and $24 .{ }^{18}$ Others suggest that the category of 'youth' constitutes some $43 \%$ of the population. ${ }^{19}$

The paper draws on two ethnographic sites in Southern Nigeria, Benin city in Edo State and southern Annang villages in Ukanafun Local Government in Akwa Ibom State. ${ }^{20}$ These offer contrasting modes of organization in relation to locality and history but have both been shaped by the dialectics of governance of the colonial and nation state. In the former there is the precolonial trajectory of a centralized kingdom with the political and spiritual head of the former kingdom, the Oba, now defined as a first class traditional ruler who is still a focus in shaping Edo identities. In the latter there is a historical trajectory of lineage based organisation in which the rights of village heads and councils were hedged in by those of a number of secret societies. The basis of Annang society has been balance

15. In Edo State this rhetorical enunciation has been taken further. At the tumultuous public welcome given to Chief Anthony Enahoro on his return from his political exile from Nigeria, Governor Lucky Igbenedion in a speech praised his past achievements but also advised his retirement 'to leave politics to the youth generation' (Vanguard, 17 October, 2000).

16. Decree No. 25 of 1987 banned all former and current public office holders from campaigning in party politics.

17. J. Lonsdale 'Political Accountability in African History', in P. Chabal (ed.), Political Domination in Africa: Reflections on the Limits of Power, (Cambridge University Press, Cambridge, 1986), p. 130.

18. O.O. Dare, (ed.), The Status of Adolescents and Youth Adults in Nigeria (1997).

19. Abubakar Momoh 'Youth Culture and Area Boys in Lagos', in Attahiru Jega (ed.), Identity Transformation and Identity Politics under Structural Adjustment in Nigeria, (Nordiska Afrikainstitutet in collaboration with the Centre for Research and Documentation, Kano, Uppsala, 2000), p. 182.

20. For a case study of localized economic responses on the south-western Nigerian coast see A. Klein, 'The Barracuda's Tale: Trawlers, the Informal Sector and a State of Classificatory Disorder Off the Nigerian Coast' Africa 69, (1999). 
between the 'open and closed' spheres of village government although in colonial and postcolonial eras these have been overlaid by the creation of 'chiefs' organized by the state as a conduit of bureaucratic governance.

This paper selects four examples from these sites in order to highlight how differing idioms of accountability respond to regimes of local governance and disorder within the nation state. It considers how a rhetoric of accountability is dispersed throughout southern Nigeria and how specific local discourses overlap despite their different historical trajectories and forms of social organisation to converge as a means of collective action in engaging with the nation state. As Mbembe suggests, areas below the state sphere are where new forms of belonging and social incorporation gestate, with the formation of 'leagues', corporations' and coalitions that use a common rhetoric. ${ }^{21}$ These are not necessarily overtly political movements but they do constitute visible, if ambiguous, sites where new normative systems, new common languages, and the constitution of new regimes of governance are being negotiated.

The two ethnographic sites highlight the ways in which people do not simply acquiesce to or oppose the political instrumentalization of disorder but rather come to terms with it by means of mediation, by inserting themselves within political and economic niches. It examines local responses to disorder and the idioms of accountability in which they are framed, and it emphasizes historical trajectories of these idioms as opposed to reductionist explanations of 're-traditionalization'. The focus of the first section on youth associations assesses local responses to the 'economy of plunder', the acquisition, by the representatives of public authority, of economic resources for private purposes. ${ }^{22}$ The second section discusses the significance of an overlapping of youth, community and religious identities in the context of urban 'area boys' and their contests over the rights to brokerage roles. The third section addresses the emergence of vigilantes and the familiar frameworks of agency and knowledge in which they operate. The fourth section discusses cults in the context of shared discourses on political and economic marginalization. And the conclusion illustrates how each of these collective responses is interconnected in the practice of local governance in southern Nigeria.

Youth Associations and the Politics of 'Squandermania'

21. Mbembe, On the Postcolony, p. 93.

22. Béatrice Hibou 'The 'Social Capital' of the State as an Agent of Decpetion or the Ruses of Economic Intelligence', in Jean-Francois Bayart, Stephen Ellis, and Beatrice Hibou (eds.), The Criminalization of the State in Africa, (James Currey, Oxford, 1999), p. 71. 


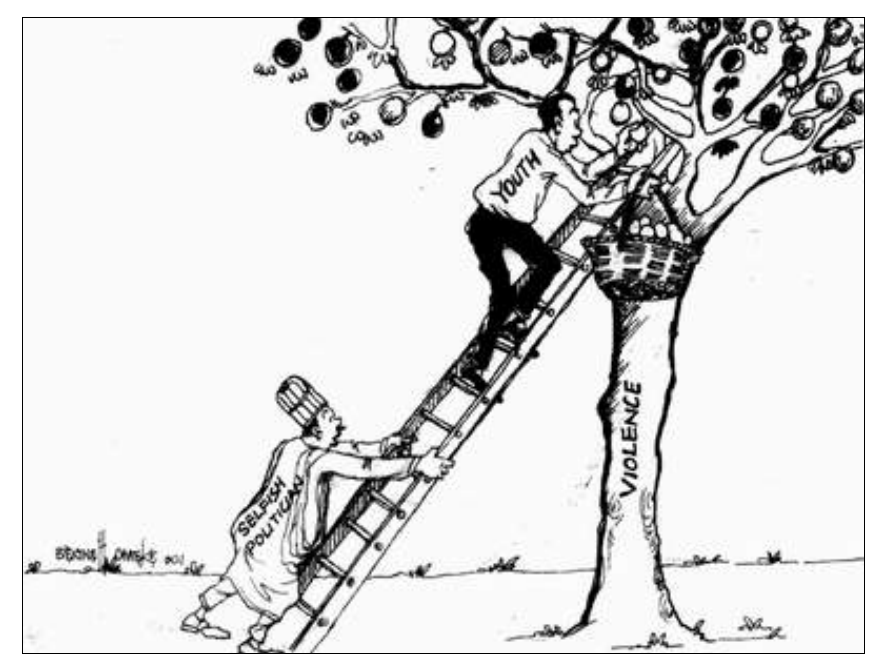

Punch, 15 October 2001

After the Civil War, the oil boom and the development of the rentier polity in the 1970s introduced a strong centripetal force and entrenched a powerful distributive principle into Nigerian politics. ${ }^{23}$ Subsequent regimes, both military and civilian, employed a rhetoric of political and economic equity in idioms such as 'federal character' and policies of 'quotas' and 'zoning', but in practice introduced a process which hardened channels of neopatrimonial or prebendal re-distribution. ${ }^{24}$ Since independence the state's control over economic resources has increased and has concentrated in its own hands control of economic opportunities. Access to the state has therefore become a precondition for doing business successfully, and economic centralization in Nigeria has generated particular local modes of engagement between society and state. ${ }^{25}$

Where resources have not been generated locally from taxation, and where policy implementation at the local government level has been highly dependent on central state subsidy, the material basis for 'liberal' democratic struggles for accountability and control has been limited. As a result, as Guyer argues, people engage with the state through other means, especially through securing and making claims on public office. ${ }^{26}$ This imperative if unpredictable link to central and corporate sources of finance in turn gives rise to modes of clientage and prebendalism which dominate the Nigerian political landscape. The replacement of certain functions of local government by office holders, chieftaincy and private organizations has resulted in an organizational complexity with overlaps and gaps that demand the constant vigilance and involvement of communities and their elites to keep their collective as well as sectional and personal interests represented. Hence, Guyer highlights the significance of a locus of labour-intensive engagement between what she frames as the corporate and non-corporate sectors, especially among the rural elite and self-

23. Tom Forrest, 'The Political Economy of Civil Rule and the Economic Crisis in Nigeria (1979-84)' Review of African Political Economy 35, (1986), p. 4.

24. These national discourses clearly presuppose local idioms of accountability and re-distribution (Richard A. Joseph, Democracy and Prebendal Politics in Nigeria: The Rise and Fall of the Second Republic (Cambridge University Press, Cambridge, 1987)).

25. S. S. Berry, 'Social Institutions and Access to Resources' Africa 59, (1989), p. 50.

26. J. I. Guyer, 'Representation without Taxation - an Essay on Democracy in Rural Nigeria, 1952-1990' African Studies Review 35, (1992), p. 59. 
styled youth leaders, who engage in party political mobilization and who address 'public' issues. It is the vigilance of local elite-led youth associations that this section addresses.

The institutions of governance in contemporary Nigeria have become a means for allocating patronage and are instruments of political domination in local communities. ${ }^{27}$ This point suggests an inherent duality to local perceptions of and responses to these institutions: conciliatory and adversarial. Institutional offices are pursued to be 'captured' for purposes of re-distribution, and are to be challenged or avoided when used for local political domination. The two approaches are inter-connected, notably in the 'rhetorical' and instrumental use of challenges against institutions (especially when framed as accusations of corruption, or as charges against marginalisation). This is a trend in which political opponents challenge their exclusion from the state in the hope that their agitation will secure their own co-optation. ${ }^{28}$ Analytically, however, it is important to refrain from consistently conflating these two conciliatory and adversarial responses within a thesis of political instrumentality. Such an overarching approach underplays the significance and ambiguity of local modes or 'moral economies' of accountability. Crucially what is lost in an overarching 'instrumentalization of disorder' approach is the situated nature of local responses, and the overlapping and inter-weaving of what Ekeh delineated as the "two publics' - one of bureaucratic accountability (the amorality of the 'civic public'), the other of community modes of justice and equity in the 'primordial public' ${ }^{29}$

Annang youth association engagement with the institutions of governance draw upon two imperatives: political representation and accountability. For Annang communities the post-colonial politics of 'improvement' rest on the construction and strategic implementation of identities. The overt political mobilization of youth associations not only to secure power, but to engage in national distributive networks, is justified under the rubric of 'improvement' and progress based on this political representation (ukara idem self-rule). Being represented by a member of a community with which one can identify, and 'having a chairman from the same place' is of paramount importance. It is in this context that youth associations 'screen' politicians before they are supported to stand for elected office. Such groups, as faction makers, are expressing their palpable potential to be coopted but in the screening process are asserting their rights to be 'remembered' as clients. The Nkek Youth Development Association, for instance, examine a candidate's 'accountability' and reputation, they will assess his or her manifesto, what the candidate will offer to do for the group and the community, their parental family (whether they were 'greedy' or 'gossiping'), whether they have been 'insulting' or 'stubborn', and whether they have committed a crime. A decision on who to support for individual offices is then made within the association and the members sign a document or swear an oath that they will vote en bloc for the candidate they have decided upon.

At the same time, youth association strategies play on Annang conceptions of accountability. Beyond financial accounting (ekot ibat), the account one makes of oneself within Annang society is judged in performative terms on the basis of the 'achievements' acquired for one's people (se enye anam - your achievements for your people). These achievements, recounted in the obituaries of big men (akamba owo) are key indicators of personal progress - ackpokpor inyene (personal wealth). Wealth begets responsibilities and it is in these aspects that one's achievements are judged in terms of sending children to

27. Vaughan, 'Assessing Grassroots Politics', p. 502.

28. Chabal and Daloz, Africa Works, p. 26.

29. Peter Ekeh, 'Colonialism and Two Publics in Africa: A Theoretical Statement' Comparative Studies in Society and History 17, (1975). 
study overseas; educating poor people through sponsorship; donating in church; employing people in a company; entertaining visitors; holding the peace; and being truthful and steadfast. In short, accountability is judged in patrimonial terms. And in practice such relationships are fraught. A common metaphor employed in Annang songs to express the failure of patrons to re-distribute is the mechanism of the rotating credit group (utibe) and the playing off within it of personal self-advancement against accountability to clients. Young clients to a club patron (ete utibe) are drawn in to contribute but rarely receive their 'hand' early in the cycle, and are often frustrated should they need credit quickly. Hence, people say, 'Its not the same mouth you use to invite someone to join your utibe that you use to give them the money they've contributed to the club.'

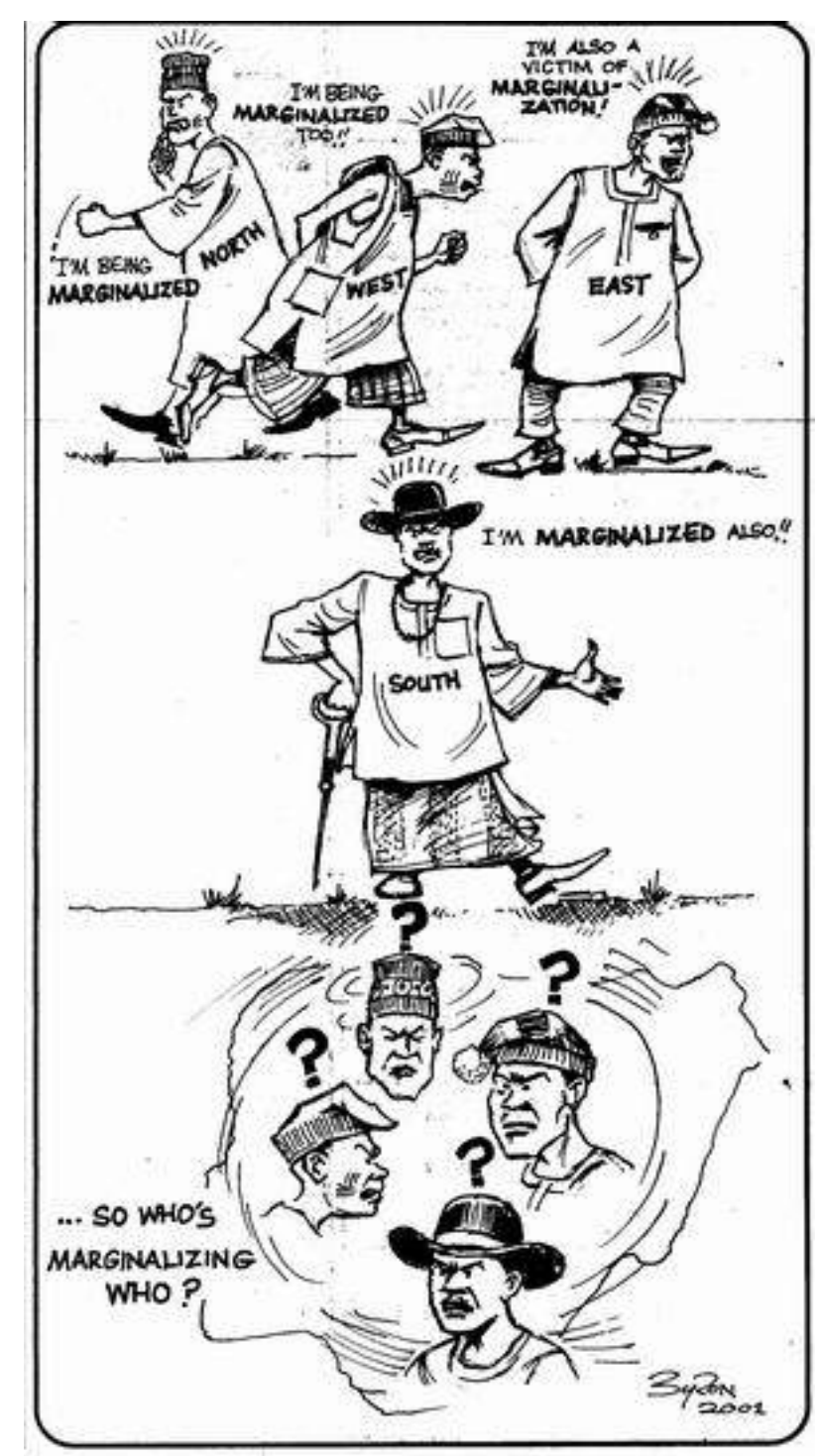

Tell, 22 October 2001

The fear of domination and marginalization resulting from a 'crisis of patrimonialism' and the inequitable re-distribution of national resources has led to regional, ethnic and a multiplicity of localized responses. These are captured in a discourse on 'corruption'. This discourse on corrupt practices describes not merely the connivance of formal administrative and judicial bureaucracies but their active manipulation. As such 'corruption' is a marker of difference which distinguishes those with 'power' and those without and acts to delegitimize the provenance of wealth and power gained from engagement with or within the 
bureaucratic infrastructures of the nation state. The rhetoric of corruption maps the contours and boundaries that are drawn along ethnic, regional, religious, gender, class, and rural-urban lines. This results in a proliferation of internal borders, whether imaginary, symbolic, in economic or power struggles where, '... the exacerbation of identification with particular localities, gives rise to exclusionary practices.' 30

This discourse on corruption is highlighted in the trajectories of Annang collective action during the twentieth century in which improvement unions and their elite leaders have sought ethical probity in public office-holders. ${ }^{31}$ The local government reforms of 1976 and the formation of Local Government Areas mark a significant rupture in the nature of state-society engagement in the development discourse. It is possible to chart a trajectory from this point in which south-western Annang development associations shifted their focus from community development on the basis of self-help to monitoring and petitioning for state help from local government. The characteristic features of youth association engagement with the state after 1976 are captured by a union formed in the Ukanafun district at the time called Atang Anan ('Do what you say'). As its name suggests, Atang Anan, which petitioned for compensation for the land and palm plots on which the local government headquarters were built, employed a rhetoric of public accountability to ensure Ukanafun's place in the distributive process. It also drew upon local understandings of the rights and roles of youth. The qualities by which a young man (akparawa) is distinguished is public speaking (atang iko otu - to speak words in public). As lines of patrimonial inclusion and exclusion were reproduced, this further implied screening and counter-acting the perceived excesses of successive council chairmen.

In 1985, for instance, Atang Anan's successor, the Ukanafun Youth Association, reported to the Cross River State Review Panel that, 'From 1979 to 1983, there is no evident progress in Ukanafun due to inflated contracts, kick-backs, corruption, misappropriations and gross embezzlements. ${ }^{132}$ In 1986, the Federal Military Government engaged in a programme to co-ordinate community development activities and to encourage the registration of development associations under the Directorate for Food, Roads and Rural Infrastructure (DFRRI). While its projects were designed to include locally mobilized inputs, the funding formula was heavily skewed towards outside investment, and in Ukanafun, as elsewhere, DFRRI funds became subject to the 'politics of plunder'. In this context the Ukanafun Youth Association again concluded that the Chairman's actions had ruined the area's development prospects:

With ghost contracts, ghost completion certificates and ghost contract payments our Directorate for Food, Roads and Rural Infrastructure is a failure in Ukanafun. ... We envisage an empty purse for our council at his rate of squandermania. ${ }^{33}$

The pattern continued. In September 1994 the Ukanafun Youth Association called on

30. Mbembe, On the Postcolony, p. 87.

31. In the Annang region the dominant antecedent is the Ibibio Union and its engagement with the provincial public sphere during the early 1940s. In 1941 and 1942 delegations of Ibibio Union members conducted 'enlightenment campaigns' in the Ibibio and Annang districts holding public lectures in council halls. Leading the 'subjects of instruction' of the Ibibio Union's campaign were exhortations to pay tax and oppose bribery. Anti-corruption was a key plank in the progressives' attack on the Native Administration system and contributed significantly to the credibility of the educated elite's own claim to political legitimacy (David Pratten, 'Progressives and Power: The Political Trajectories of Old and New Elites in Eastern Nigeria, 1930-1947' (paper presented at the Biennial Conference of the African Studies Association of the UK, Trinity College, Cambridge, 11-13 September 2000).

32. Ukanafun Youth Association to Cross River State Contract Review Panel, 25 April 1985.

33. Ukanafun Youth Association to Military Governor, Cross River State, 17 April 1987. 
the state military administrator to transfer 'fraudulent and dubious' senior staff of Ukanafun Local Government, including the secretary, senior technical officer (STO), and treasurer. The request was submitted, it claimed, to 'forestall impending riot and loss of life', and read as follows:

1. The STO issued fake completion certificates for unfinished jobs therefore defrauding the council of millions of Naira. The council recorded a total income of N67.65 million but had no project to show for it;

2. From 1990 the STO personally acquired 4 vehicles, 1 private car, a 12 bedroom bungalow worth N800,000, a Lister generator, an 8" borehole with overhead tank;

3. The secretary collaborated with the Treasurer to authorise 'ghost contracts';

4. That the group were seen at the LG treasury on Saturday and are suspected of destroying documents and preparing others for presentation to the Task Force on Recovery of Public Property by Caretaker Committee of Ukanafun Council;

5. They are now resorting to the services of wizards and demonic forces.

We do not yet want to take the law into our hands but we will be forced to if these wicked and heathen fellows do not leave Ukanafun immediately. ${ }^{34}$

Such rhetoric employed by contemporary youth associations has particular features of note. The threat of violence and the invocation of non-Christian religious idioms are the poles against which notions of community 'good' are contrasted, while detailed knowledge of personal accumulation and the techniques of state bureaucracies are the bases upon which claims are legitimated. It is a rhetoric of exposé directed at patrons and re-distributors in the patrimonial power webs including not only local government chairmen but also lineage heads and village chiefs. The construction of this imagined moral community is based on the language of legitimacy forged from progressive and Christian rhetoric and is expressed in the grievances of the 'concerned citizens' of communities across southern Nigeria. ${ }^{35}$

As Olivier de Sardan says, it is hard to isolate acts of denunciation from the factional politics of which they are part. ${ }^{36}$ This is manifest in those claims and charges brought by elite associations for whom the community well-being is advanced when patronage, positions and contracts are more likely to accrue to the community at large and the rival faction in particular. This is achieved by removing 'outsiders' responsible for the mismanagement of local government, and by destabilising local politics when those elected representatives are from minority opposition parties and do not have a link to the centre, a phenomenon of local politics known as the 'party in power syndrome'.

Beyond the violence and instability of the politics of 'corruption' it is important to recognize the linkages between youth associations operating in this sphere and the state. Claim-making and petition-writing concerning the accountability of public office-holders, are brought into the public sphere by such groups but depend on resolution through the bureaucratic procedures of the nation state. The state is appealed to as the upholder of the law and may use its sovereign power in matters of contested rights. This by definition legitimates the state and the state's means of dealing with alleged corruption irrespective of personalized patrimonialism within it. The events of 2001 in Ukanafun where the most recent local government council chairman was removed from office is a case in point.

34. Ukanafun Youth Association to Military Administrator, Akwa Ibom State, 12 September 1994.

35. As Gupta has argued for the Indian context, discourses of corruption articulate both with the intersecting of different transnational forces and with distinctive historical trajectories (A. Gupta, 'Blurred Boundaries: The Discourse of Corruption, the Culture of Politics, and the Imagined State' American Ethnologist 22, (1995), p. 393).

36. Olivier de Sardan, 'A Moral Economy of Corruption', p. 49fn. 
Despite the presence of hired political thugs, burning tyres on the road and armed clashes which led up to the event, the chairman was impeached by the councillors in the chamber of the council hall according to the constitution. ${ }^{37}$ Despite the appearance of crisis, the means by which communities respond to apparent disorder contributes to a mode of governance which is dependent on validating the procedures and disciplines of the postcolonial state.

\section{From Age Grades to Area Boys in Benin City}

For many individuals excluded from access to the resources of the nation state and without viable political, social or economic purchase with which to insert themselves into the state, the resources of localized collective identity are an important means of laying claim to and securing rights in resources and economic transactions. Hence in most of the major urban centres faced with intense competition over land, accommodation and economic opportunities distinctions between 'indigenes' or 'sons of the soil' and 'strangers' have become commonplace. Such a distinction is marked in the emergence of 'Area Boys', a collective grouping which comprises local, young individuals with a close social and spatial identification with a particular area. While these groups are defined in terms of age and generation, they are crucially constituted by their community of origin, and serve to reshape its boundaries in turn. In their use of petty entrepreneurship and casual labour 'Area Boys' economic activities, are for the most part, ambiguous in relation to the strictures of the state infrastructures and at times move into explicit criminal activities. Yet, in their identification with an area and as part of a community they lay a collective claim to the right to access those local resources from which they are often explicitly excluded.

Across Nigeria such modes of youth organisation have shared remarkably similar historical and cultural trajectories. Despite their localized forms, the various contemporary urban youth gangs share a number of characteristics in common: they draw upon precolonial idioms of organisation in which young men were enforcers of community rights, morals and laws; they have (re-)emerged under the combined effects of SAP liberalization and post-Cold War privatization; and they have been successively criminalized since the late 1980 s as a result of links to the expanding drugs trade and to their use of violence in religious and ethnic riots and political protests. Patronage and the possibilities of gang-ownership has brought these groups into secretive links with the business and political class. Indeed, the solidarity and secrecy of urban youth gangs present especially malleable 'social capital' in a context of the criminalization of politics. ${ }^{38}$

Area Boys in Lagos, for instance, took an organized form from around 1986 though the concept draws on idioms of the Lagos Boy (omo eko) and street boy (omo adugbo) each associated with particular neighbourhoods and the celebration of Fanti and Eyo festivals. Antecedents of Lagos Island area boys during the colonial period, the 'Alikali boys' who paraded and caused trouble at Christmas and Easter, echoed many features of masquerade

37. As a result of the impeachment disputes in Ukanafun during 2001 regarding the alleged embezzlement of funds by the local government chairman, the representative to the state House of Assembly called an 'Accountability Meeting' (adiwot senam - to show your achievements). It was organized by his supporters, and was widely interpreted as a public relations exercise to deflect suspicion concerning his own dealings.

38. Jean-Francois Bayart 'The 'Social Capital' of the Felonious State or the Ruses of Political Intelligence', in Jean-Francois Bayart, Stephen Ellis, and Beatrice Hibou (eds.), The Criminalization of the State in Africa, (James Currey, Oxford, 1999). 
performance. ${ }^{39}$ The recent criminalization of Area Boys in Lagos has been linked to their role as intermediaries ('strikers') within the expanding drugs trade, to their recruitment as political thugs in the Babangida transition and to their prominent role in protests, against SAP (in which they joined forces with students from the University of Lagos) and against the annulled 1993 presidential elections. The Hausa Yandaba are similar neighbourhood gangs. In Kano the idea of Yandaba is associated with hunting ( $d a b a$ refers to a hunters camp) and forms part of a cluster of types including political thugs (Yanbanga - a Hausa adoption of the English word 'vanguards') and hunters immune to metal weaponry (Yantauri). Yandaba have been seen as a means of socialization to adulthood yet their image as community enforcers, cleaning streets and providing protection against theft, has been undermined by involvement in riots in the early 1990s and in elections as henchmen for rival politicians, though they are still active in providing volunteers to local vigilante groups. ${ }^{40}$

Membership of area boys' groups in Benin City is defined by residence and age but resonates with the pre-colonial traditions of age grade sets which the groups often acknowledge as serving to define their local collective identities. Benin City is the capital of Edo state and is also the centre of the Edo kingdom ruled by the Oba of Benin until its annexation by the British in 1897. The rule of the Oba was restored in 1914 within the policy of indirect rule and is now incorporated within the infrastructures of the nation state as the legitimate traditional ruler. Underpinning the Oba of Benin are institutions which also pre-date the colonial incursions and include specialized guilds which regulate their products or services within particular areas, of which the brass-casters guild is a notable example. Patrilineages are small, and political power at both village and state level is not conceptualized in terms of lineage representation. ${ }^{41}$ Most migrants to the city, in fact, trace paternal descent to one of the many surrounding villages where the youth are organized into age sets known as ighele under the directions of the village elders.

In the rural areas of the Edo kingdom, a three tier age grade system operates in the villages as well as wards of Benin City. The top tier is the edion (elders), headed by the odionwere, the oldest man in the village, who being closest to the ancestors mediates with them on behalf of the village. The edion distribute land, control the resources of the community and mediate with external authorities. The elders directed the warrior and executive grade of adult men ighele while the youth iroghae performed the mundane tasks of village maintenance such as sweeping village paths at daybreak. The iroghae vary in age from 15 to between 30 and 40 years depending on when the changeover from iroghae to ighele takes place. In the postcolonial nation state this age grade system still regulates

39. Simon Heap, 'Colonial 'Area Boys': Male Juvenile Delinquents on Lagos Island' (paper presented at the Biennial Conference of the ASAUK, Trinity College, Cambridge, 11-13 September 2000). Across the continent from the 1920s onwards, especially during the second world war years youth gangs, including the various Cowboy cults, were perceived as a menace to colonial law and order during festival periods (Andrew Burton, 'Urchins, Loafers and the Cult of the Cowboy: Urbanization and Delinquency in Dar Es Salaam, 191961' Journal of African History 42, (2001)).

40. Yunusa Zakari Ya'u 'The Youth, Economic Crisis and Identity Transformation: The Case of the Yandaba in Kano', in Attahiru Jega (ed.), Identity Transformation and Identity Politics under Structural Adjustment in Nigeria, (Nordiska Afrikainstitutet in collaboration with the Centre for Research and Documentation, Kano, Uppsala, 2000).

41. Bradbury suggests that the lack of effective lineages is due to a high rate of population movement in precolonial times between villages and to the urban centre of Benin City and to the particular pattern of land rights which are controlled by the edion (R. E. Bradbury, The Benin Kingdom and the Edo-Speaking Peoples of South-Western Nigeria, vol. XIII, Ethnographic Survey of Africa (International African Institute, London, 1957)). 
village life though many youths migrate to Benin City. While the Oba's palace and its societies in the city have served as a magnet for the upwardly mobile since pre-colonial times, it is niches within the urban cash economy which attract young villagers today. In part also release from the political and spiritual control of village elders leads young men to the city. In referring to villages a common complaint of youths who were resident in Benin City in the 1990s of their natal village is that 'the village is full of witches' by which they refer to the elders' capacities to expropriate their labour and resources. However, in the city economic niches, mainly available in the informal modes of employment, result in low incomes and high levels of insecurity.

Benin City has many Area Boys groupings associated with local residential areas, although these tend to be organized more formally where economic benefits or work opportunities are more readily available such as at transport interconnections, or markets and other specialized work areas. Residence provides a boundary, albeit a permeable one, that excludes from participation those non-Edo speaking residential groups who have settled near inter-regional transportation links. Area Boys can also be aligned in various contexts of inter-dependent relations with local shrines as well as with the various orthodox and evangelical denominations of Christianity. Notions of the restriction of access to knowledge constructed through the initiation rites of these shrines finds a common chord with the sense of community required for Area Boys. The association of particular deities, such as Ogun, with gender differentiation among male age grades finds a particular correspondence in Area Boy groups, especially those involved with transport with which Ogun is linked as the deity of war and metal. Indeed many drivers and mechanics actively seek initiation into Ogun or undergo extensive rituals for protective medicines against crashes, armed robbery and other potentially hazardous consequences of their work. The dynamics of membership of shrines and the construction of this sense of community, while providing spiritual solidarity, also involves the formation of patron-client relations between the young Area Boys and more socially established and successful individuals through which access to scarce resources can be obtained.

Area Boy groups seek to control a defined locality with which they are linked residentially in order to regulate the flow of goods and services to their advantage. This can take the form of the offer of the first casual jobs available at a market location or being placed in a supervisory role to minimize disruption or pilfering. The operation of motor parks, in which urban area boys, and increasingly village youth groups, seek employment are typical sites for these contests. 'Sons of the soil' have fought for rights against local councils and the National Union of Road Transport Workers to issue daily operating licences and to collect commission from vehicle loading in towns and villages across the south. In many cases such rights are limited to times outside normal operations, on Sundays or after $5 \mathrm{pm}$ for instance. Since access to even these marginal resources are scarce they are subject to keen competition and these claims have contributed to conflicts both between 'sons of the soil' and have exacerbated indigene- 'stranger' tensions.

Much of the corporate status and legitimacy within the wider community rests on the role of area boys as vigilantes, exacting punitive retribution on outside thieves who prey on the community. Their failure to provide security, or at least monitoring of criminal activities, calls this legitimation into question, and instead of being framed as a contemporary urban form of age set with assigned duties of guardianship, they are suspected of being the criminal perpetrators themselves and are alienated from the moral community to which they nominally belong as its area boys. For example, on an almost annual basis at Christmas time in New Benin market when the stalls are full of festive and expensive goods fires are started at night in the market in order to provide the pretext for 
large scale looting. The inevitable consequences are the wholesale destruction of the market which levels the apportioning of blame which would otherwise be directed at those stalls that had not been looted. The various groupings economically affiliated to the market, including the market traders association and the area boys, convene meetings of their groups to discover and hold accountable the perpetrators. The causes of the arson and the consequent looting are attributed as lawless acts committed by individuals outside the local community and conceptualized as outside its moral boundaries, even if evidence is ambiguous and locals are suspected.

Area boys will often have formal and informal patrons who will support them financially or sponsor social events in which they are involved. In return the patrons secure extra security, political support and a means of effecting disorder. ${ }^{42}$ In the imposition of disorder, such as the cessation of state regulated market activities, the Area Boys define the boundaries of a local moral community and modes of accountability within it. Mutual support in times of crisis or financial difficulty is a strong element of Area Boy groups, and is significant in the constituting social events which are imposed upon and serve to shape the wider community. At New Benin market the news of the death of a bush taxi driver in 1996 precipitated the complete cessation of long distance transport. Area Boys and drivers blockaded the road with vehicles and tied leaves to the car fronts for the rest of the day to indicate mourning for the calamitous event. The form of mourning was imposed on all market stallholders who were unable to transport goods, and even though some had little vested interest in the tragedy they were still incorporated by their participation into the moral boundaries of the local community. Failure to participate in such an event results in punitive sanctions and exclusionary tactics which, in extreme cases, may force the stall holder permanently to quit the market.

Area boys are a response to the migration and the influx of 'strangers' into urban areas. Fears of economic and political marginalization among young, unemployed urban indigenes leads to contests led by youth gangs, sometimes violently, which appear petty, mundane and economically marginal, but which reveal two important points. Firstly that such disputes concern rights of resource access in which claims are based on the deployment of various identities, where indigenity is the legitimating 'trump' card. And secondly, such contests demonstrate the significance of economic niches, especially those positions which intersect transactional flows, and the creativity of aspirants to insert themselves into such niches. Area boys emerge as a social grouping by shared local conceptualisations of age grades to define a wider community and assert a set of economic and political rights. By these means they demand to be taken account of by patrons, market and transport operators within a given area. Their insertion into forms of patrimonialism upon which they are in fact dependent co-opts them into an ambivalent moral space in which there is an ongoing dialectic between local forms of moral accountability for the benefit of the wider community and the instrumental means of economic survival for excluded and marginalized youth. Moreover this assertion is part of the 'making of' patrimonialism as a mode of order. Within the dynamic contexts of identity politics in Nigeria the ambiguity of the roles area boys assume and the rules they enforce requires an ongoing process of re-legitimation of their activities and redefinition of their community within grass roots idioms of accountability. These processes contribute to a decentring of area boy identities as fragmented and fractured within the practices of everyday life in relation to wider processes of governance.

42. John W. Nunley, Moving with the Face of the Devil: Art and Politics in Urban West Africa (University of Illinois Press, Urbana and Chicago, 1987). 
From Secret Societies to Vigilantes

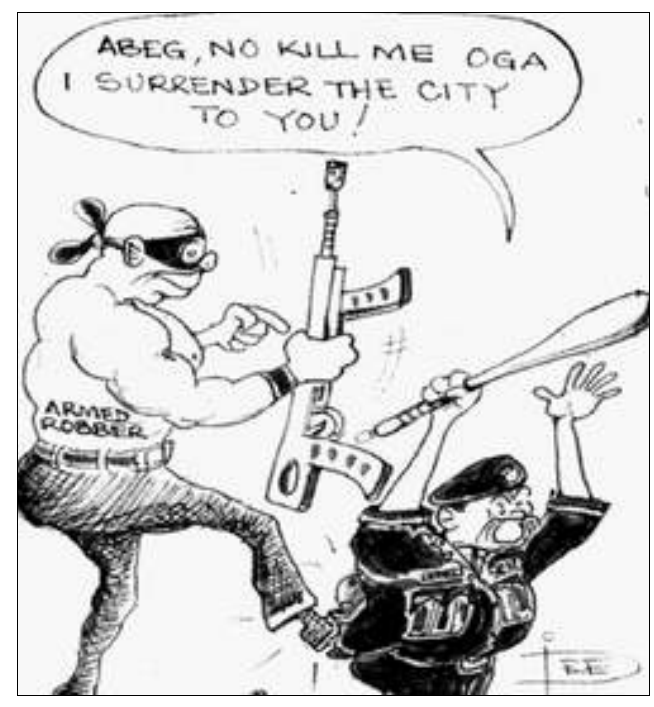

Independent Monitor, 6-9 September 2001

Vigilantism in Nigeria has recently assumed a high profile status as each of the socalled 'ethnic militias' which have emerged since the democratic transition in 1999 has assumed some degree of vigilante activity. In particular, the legal sanctioning of State Vigilante Services in south-eastern states known as the Bakassi Boys continues to pose fundamental questions of the very constitution of the Nigerian federal state. Yet, since the late 1980s the widespread growth of night guards has been a popular local response to theft and armed robbery. Across Nigeria from rural lineage to urban district vigilantism has become endemic as vigilante groups contest with those authorities, especially the Police and traditional rulers, prerogatives over the reporting and judgment of crimes.

Throughout the country, vigilantes draw upon modes of social action in which young men of the community protect and punish. In Northern Nigeria, contemporary vigilantism draws upon a religious idiom. Popular pressure for the implementation of sharia law in the northern states of Nigeria since 1999 can be seen as a grassroots response to government mismanagement, to the failures of the judicial system and to the inequalities experienced by those young men who invoke piety as a political act and join vigilante groups to enforce the sharia code. These vigilantes are known as hisba, drawing on a classical Arabic term with overtones of legitimacy in maintaining discipline. ${ }^{43}$ According to Murray Last, the statement these Muslim vigilantes are making in invoking sanctions against adultery, drinking alcohol and spirit possession is an indirect one, that reform at home should be met with reform at the national centre.

In south-eastern Nigeria the dominant idiom in which vigilantism is manifest is the secret society. The popular video 'Issakaba' (a two-part drama highlighting the role of the Bakassi Boys released in 2000 and 2001) captures a trajectory which captions describe as chronicling 'the mind blowing exploits and rituals of a secret society turned vigilante group and their battle against crime. ${ }^{44}$ The film resonates with images of truth-telling charms,

43. Murray Last, pers comm.

44. Though the Bakassi Boys draw on the idiom of community guards (ndi nche) there is apparently no direct historical path from 'ancient' secret societies to the current state vigilante services. The Bakassi Boys 
ritual protection and death-defying ordeals readily identified and appropriated by young men in nearby Annang villages. The impact of the Bakassi Boys has indeed served to validate and embolden youth vigilante action and the rhetoric of moral justice they espouse. ${ }^{45}$ The symbolic dimension of the discourse on crime, of charms, shape-shifting and of secrecy, feeds directly into the idioms of organisation through which both criminals and counter-criminals organize themselves. In this way vigilantism draws on the pervasive idiom of the secret society.

Contemporary Annang vigilantes contest, or have assumed many of the functions of pre-colonial secret societies (ekpo, ekpe and ekong). Parallels with the societies are evident in oaths of secrecy sworn by the vigilante members, ufok usung road blocks, and in modes of punishment. The secret societies therefore offer not only a model of organisation, but also a transmission of practices common to a range of organisations. Armed robbery, known as 'amauke!' ('your money or your life!') was first reported as an outbreak as the 'menace of a secret society of criminals' in Uyo in $1959 .{ }^{46}$ Shortly after the civil war, resulting from unemployment and demobilization, Nigeria witnessed a rapid increase in armed robbery incidents. In response the Federal Government of Gen. Gowon promulgated the armed robbery and firearms decree of 1971. Locally such measures had limited effect and the style of popular justice in Ibibio-speaking communities continued. In Nsit Atai during 1979, for instance, a celebrated armed robber 'disappeared' on the order of ekpo ndem isong, the ekpo-led village council whose judgements were carried out clandestinely. ${ }^{47}$ Indeed, vigilante action, based directly on secret society revivals or drawing indirectly upon the idiom of the secret society, has been a common response to crime since the Civil War. Contemporary vigilantism therefore represents the articulation of claims to a set of rights based on the historical and spiritual legitimacy of young powerful men, 'sons of the soil', defending the village under the protection of locally reputed charms, medicines and oaths.

Contemporary vigilantes are often organized by or have developed out of hometown associations. In the current economic climate self-help development projects, for so long the annual raison d'etre of hometown associations, have been scaled down, abandoned and disputed. From their inception in the late 1920s onwards these associations have asserted rights to judge members' disputes internally and to supervise their dealings with the formal legal authorities ${ }^{48}$ It is of no surprise then that these core functions should come to the fore in a context of economic scarcity and when instrumentalized disorder adds to the precariousness of everyday life. Indeed, vigilantes led or sponsored by improvement unions must be viewed alongside the petitions and protests against police harassment and law and

originated as guards of the shoe repairers market in Aba. Rather, such captioning expresses a popular imagining of historical links and re-inventions of cultural frameworks.

45. Frequently disputes over 'protection money' levied on businesses and households in Annang villages and elsewhere lead to violence. In one such case in Ikot Akpa Nkuk, when the vigilante member was reprimanded, he complained that in their operations the much-lauded Bakassi Boys were able to 'act as they pleased.'

46. Udo Udoma, The Story of the Ibibio State Union (Spectrum Books, Ibadan, 1987), p. 495.

47. D. A. Offiong, Continuity and Change among the Traditional Associations of Nigeria (Ahmadu Bellow University Press, Zaria, 1989), p. 45.

48. Improvement unions, like the secret societies, transcended lineages, and direct parallels can be drawn between unions and societies in common arenas such as burial and performance, in idioms of membership and secrecy, and in the prosecution and punishment of crime. These parallels are rarely drawn explicitly in other studies, however, with the notable exception of Ruel's account of political organisation among Banyang communities of the upper Cross River region (M. Ruel, 'The Modern Adaptation of Associations among the Banyang of the West Cameroon' Southwestern Journal of Anthropology 20, (1964); M. Ruel, Leopards and Leaders: Constitutional Politics among a Cross River People (Tavistock Publications, London and New York, 1969)). 
order issues submitted by the unions themselves.

In the Annang village of Ikot Akpa Nkuk the youth association, Mboho Ade Uforo Ikot Akpa Nkuk (MUKAN -'Unity for progress'), formed security patrols called 'vanguards' in 1988. Following the collapse of a development project, members and villagers alike admitted that 'without the security patrols the name of MUKAN would be no more.' Since 1988, the vigilante patrol has blown the uduk mkparawa (youth horn) when suspicions were aroused which imposed an all-night curfew and would mount road-blocks on the bush paths leading to the village. Their responsibilities were defined as follows:

1. Every member of the Association is empowered to arrest and interrogate anybody caught stealing or suspected to have stolen and report them straight to the Police.

2. Mount routine patrols at markets to check for suspects and stolen goods

3. Those caught buying stolen goods will be reported to the village council and to the Police.

4. Mount road blocks at night in some streets in the village to trap thieves. ${ }^{49}$

By 1997 MUKAN recorded 23 cases of parading thieves, and 18 cases in which suspects caught by the vigilante group were later convicted in the Magistrates' Court. Its most notable success came in 1996 when four armed robbers were captured at the main road junction in Ikot Akpa Nkuk. The robbers were subsequently executed by firing-squad by the Police. The event is seen locally as having acted as an effective deterrent against further incidents.

Vigilantes like MUKAN in southern Annang communities arose to counter a rise in armed robbery from the late 1980s onwards. Their emergence represents an indictment not only of the police (especially their ineffectiveness at night), but also of the customary sphere of law and order in Nigeria. The maintenance of law and order is a key performative criteria for village chiefs who have been under pressure from state authorities and local youths alike to employ means against rising violent crime. In Ikot Akam, like many other Annang villages, for example, villagers swear an oath at the village council in August each year. Non-Christians swear on mbiam ikpa isong, the spirit of the village, and Christians swear on verses from the Bible that if they should steal, associate with thieves or join armed robbery gangs then they would be killed within six months. ${ }^{50}$ Chiefs are under pressure by youths to endorse vigilante patrols and are frequently subject to accusations of complicity with criminals - especially of releasing thieves on receipt of bribes. Often an uneasy accommodation is reached with both the Police and the chiefs which enables vigilantes to further claim that they are acting as the executive of these formal authorities. ${ }^{51}$

Vigilantes not only bring criminals to book but also deal with domestic accountabilities. In establishing themselves as informal tribunals they hear minor cases and domestic disputes. Often vigilante group members are called upon by parents to discipline stubborn children (nchong iwuo - strong head) by 'strokes of the cane' (for persistent truancy for example) in similar ways to secret societies, ekpo in particular, who are 'hired' to intimidate disobedient children. Following their own investigations, vigilante groups may resort to punishment on behalf of the parents, though they often reveal an intergenerational

49 Mukan Memorandum, 9 December 1988.

50. Nto Udofia Ekpuk Council Minutes, Ikot Akam, September 1989.

51. Heald's analysis of the relationship between chiefs, vigilantes and the police in 1960s Uganda is informative in this respect (S. Heald, 'Mafias in Africa: The Rise of Drinking Companies and Vigilante Groups in Bugisu, Uganda' Africa 56, (1986)). The chieftaincy, undergoing a crisis of legitimacy and authority, co-operated with the vigilantes so that they might gain respect from both the police and their villages for handing over thieves to the authorities, thereby increasing their authority by gaining influence over a clandestine police force. 
economic tension between fathers and sons linked to the investment a father makes in his son's future education or trade. Where the vigilante group feel the father has not contributed sufficiently they insist that the father pay for further training or tools for a trade, which the vigilante group itself may help to subsidize.

Annang popular justice of this type is popular because it employs practices that are familiar and accord closely with conceptions of how truth and guilt are established through performance. Performance is central to Annang concepts of knowledge and oaths and ordeals are key performative devices through which people may determine truth in the retrospective attribution of cause to effect. Oath-swearing is far more than a guarantee of veracity, it is an ordeal through which oath-takers live and hence an indication of guilt should they die. ${ }^{52}$ The popular legitimacy of some village vigilante groups in their role as alternative judicial fora is therefore linked to the use of ordeal ( $u k a$ ?) in establishing guilt in cases of theft. In one instance in Ukanafun, the vigilante leader is an uka? ordeal specialist who investigates cases of theft with recourse to a tract from the Bible. A key is placed inside the Bible and the ordeal-giver calls on the spirits of thieves in the Bible to identify the guilty party. The suspect undergoing the test holds the loop of the key which is suspending the Bible, and if proven guilty the Bible rotates three times. In the neighbouring Adat Ifang clan, on $O b o$ market day wives prepare food, invite their parents and friends from their natal villages, and dance for the vigilantes to display their innocence from accusations of theft which is designated by wearing an eyei on their right hand.

Vigilantism is a conservative response to contemporary disorder in Nigeria and draws its legitimacy from familiar and long-standing cultural practices. Hence, vigilantism expresses a lack of confidence in the capacity of the state to offer security, but does not project a revolutionary or anti-state message. The Bakassi Boys phenomenon is not so far removed from these widespread everyday practices and neither is the state sponsorship of vigilantes or neighbourhood watches especially new in this context. ${ }^{53}$ What is significant about the close links between vigilantes and state governors in the Igbo states and elsewhere such as Edo State, and what is especially peculiar to the Bakassi Boys and is the coincidence of their emergence with a re-working of federal politics in which the power of the state governors has increased dramatically relative to the federal centre. This is directly related to the increased revenue re-distributed to state and local government levels which has made political office ever more highly prized and more vigorously defended.

\section{Secrets, Shrines and Varsity Cults}

In recent years renewed theoretical attention has focused on the domain of witchcraft and accusations of its practice by which accumulation through illegitimate means has been interpreted and checked. ${ }^{54}$ As a site of localized modernity, witchcraft, however, serves as only one idiom on illegitimate accumulation, political and economic marginalisation and criminality. Various covert or secret forms of association located within wider religious

52. On oaths and ordeal in the Ibibio-speaking area see D. C. Simmons, 'Efik Divination, Ordeals and Omens' Southwestern Journal of Anthropology 12, (1956). And comparatively on ordeals as divinatory practice and public performance see Elizabeth Tonkin, 'Autonomous Judges: African Ordeals as Dramas of Power' Ethnos: Journal of Anthropology 65, (2000).

53. Under Governor Ogbemudia of Edo state neighbourhood watches were set up established in the 1980s.

54. Peter Geschiere, 'The Modernity of Witchcraft: Politics of the Occult in Postcolonial Africa' African Studies 57, (1998); M. Rowlands and J. P. Warnier, 'Sorcery, Power and the Modern State in Cameroon' Man 23, (1988); J. Comaroff and J. Comaroff, (eds), Modernity and Its Malcontents, Ritual and Power in Postcolonial Africa (University of Chicago Press, Chicago, 1993). 
discourses of power assume considerable importance in the context of the undisclosed provenance of wealth and power. The relationship between the idiom of secrecy and accountability at the local level of everyday governance is strong. As Simmel points out the presence of secrecy includes and excludes by definition and within the contexts of local accountabilities this provides a potent discourse on access to resources within the community and in accessing the resources of the various bureaucratic tiers of the state. ${ }^{55}$ Hence, the secret cult offers a logical idiom of social action in the context of scarce resources where access to opportunity is constrained by restricted knowledge.

The various movements of protest and resistance to the national government in the Niger Delta area have led to the emergence of the Egbesu 'secret cult' which has provided local youth a collective means of organisation that cuts across the complex mosaic of identities found in the Niger Delta. The ideas and practices of the deity Egbesu legitimate and structure the actions its members take within the Niger Delta region. Political commentators and human rights campaigners have commented on Egbesu as a form of spiritual protection for youth resisting the predations of the police and army, including its reputation to protect an individual from gunfire. ${ }^{56}$ However, it is in its claims to a precolonial trajectory that rights of ownership over land and resources are defined in opposition to the colonial and subsequent nation state and these provide a key context for situating counter-narratives to economic marginalisation and environmental exploitation.

Egbesu is a resistance movement through which youth define an identity that challenges the state and the oil companies. It is the moral power of the Egbesu deity which holds accountable individuals who take action on behalf of the state and colluding companies who are perceived to have relinquished their legitimacy in their failure to re-distribute oil revenues.$^{57}$ Hence, along with the Ijaw National Congress, the Ijaw Youth Congress and others the Egbesu Boys issued the Kaiama Declaration on 11 December 1998 which demanded the withdrawal from Ijawland of all military forces of occupation. Egbesu Boys have since been branded as 'pirates' by state authorities because of their alliances and activities. Re-aligned as it is, Egbesu nevertheless remains a religious institution and its functions in Ijaw communities is to provide protection, security, and discipline. As such Egbesu constructs a moral community with the physical and spiritual security that this entails, and hence it determines when there is a just cause to use the force of Egbesu for 'the good and protection of the community.' 58

In Benin City there are many forms of religious fellowship that construct moral communities to provide protection and security. There is a wide range of religious practices and many individuals engage with more than one, especially as certain religions are seen as being more efficacious in resolving particular kinds of problems or difficulties. Personal and ancestral shrines, for instance, are found in many families and provide physical and spiritual protection for family members despite the incursions of various denominations of

55. G. Simmel 'The Secret and the Secret Society', in K. H. Wolf (ed.), The Sociology of Georg Simmel, (Free Press, New York, 1950).

56. Djoke Munday, an Egbesu member, believes he is immune to bullets. "I'm not afraid [of government soldiers]. If they use a gun to shoot me, I am not afraid of them. What I believe is that a gunshot will not kill me," he says (BBC News, November 6, 1998). Contrary to these literal readings, the assumptions on which such religious ideas and practises are based provide a means for understanding the consequences of events, especially at times of great insecurity (see E. E. Evans-Pritchard, Witchcraft, Oracles, and Magic among the Azande (Clarendon Press, Oxford, 1976)).

57. Misfortunes in the subsequent trajectories of such individuals are attributed to the deity.

58. Comments by Prof. E.J. Alagoa in Survival (Newspaper of Chikoko Movement), 2 October 1999. 
Christianity throughout the twentieth century. ${ }^{59}$ Some charismatic individuals develop their personal shrines to gain a following. These individuals gain a personal relationship to a deity through possession which is legitimized by lengthy initiation. Such shrines are successful through the formation of a community centred on the shrine through which access to physical and spiritual protection is secured. The community thus formed varies from shrine to shrine but emphasises mutual support and can also involve access to healing and sources of fertility, credit savings schemes and conflict resolution mediated by the priest or priestess.

These charismatic shrines developed within the urban cash economy of Benin City in the twentieth century and invoke precolonial trajectories of localized religious practice that delineate indigenes "sons and daughters of the soil" from uninitiated outsiders who are excluded. Membership of these shrines is through initiation in which individuals undertake to join the moral community of the shrine and not to harm other members. This is usually conceptualized as becoming a 'child' of the shrine and in enacting filial relations to the priest or priestess. A successful priest or priestess over the years can induct thousands of members, although for many of these it is a temporary or latent relationship specific to the resolution of particular problems or needs. These religious communities provide a means of ordering everyday life which overlaps with federal state governance. In political elections, for example, party agents canvass the support of established priests and priestesses in order to gain the support of their communities.

The shrines lay claim to precolonial trajectories of religious knowledge which contribute to the construction of local Edo identities. However, the religious forms they assume are open-ended and can include the acquisition of deities and their associated performances from beyond the Edo-speaking region. The Azenu deity found at some shrines, for instance, is derived from the Eshan speaking areas which although part of the historic Edo kingdom is considered a remote outpost. In the late 1990s another deity, Azigidi, has become increasingly popular and has become a central focus for constituting an informal religious network between priests and priestesses in Benin City and their communities of devotees. It is a deity that has been acquired from the Niger Delta and the language, songs, music, dance, attire and forms of possession by the deity enact a specifically Ijaw performance even where all participants are indigenous Edo-speaking individuals. This has occurred at the same time that the rhetoric of Niger Delta discourses of marginalisation have also been taken up in Edo State both within its governmental tiers and in popular discourses in the public sphere. Edo State is in dispute with other states as to its exact borders as some oil reserves cross its federal state borders and several oil companies hold long term leases for mineral rights on large tracts of land in the state, such as in Orhionmwon local government area. As the rhetoric of marginalisation has been taken up as a discourse in Edo State, so in the religious imagination of the shrines there has been an extending and incorporation of specific enactments of spirituality adopted from the Niger Delta region that make a grounding for linked identities.

59. In addition to mission and Aladura churches, the forms of Christianity found in the latter half of the 20th century include the Mormons, Jehovah's Witnesses, 7th day Adventists as well as denominations of other world religions and spiritual movements such as Hare Krishna, Guru Maharaja and the Rosicrucians. 
Despite sharing a common idiom of organisation with Delta cults, including Egbesu, shrine cults in Benin City are not criminalized. In fact, many of the priests and priestesses are officially registered by Edo State as 'traditional' doctors qualified and sanctioned to practise indigenous forms of medicine. However, they have been demonized. Benin City has witnessed a rapid growth of Pentecostal churches since the 1990s which have gained particular prominence by defining themselves in opposition to the 'pagan worship' of these charismatic priests and priestesses and to the perceived tolerance of more orthodox Christian churches to these practices. They have instigated vociferous and occasionally violent campaigns against the shrines, indicting them as 'secret cults' advocating pagan devil worship in ways which resonate with local notions of witchcraft. ${ }^{60}$

The most visible 'secret cults' which have been both demonized and criminalized, however, are found on Nigeria's university campuses. On the university campuses there has been long standing associations of students as confraternities. In Edo State the University of Benin and Ambrose Alli University have such student groupings which range from social leisure activities such as the Palm Wine Club to a number of confraternities of which the most well known is the Pyrates formed in 1952. The application of the Structural Adjustment Programme from the mid 1980s, however, had a major impact on students and their representative bodies. By the late 1990s massively increased fees, higher student-totutor ratios, increasingly poor learning and living conditions, exploitation of students by some lecturers, and authoritarian management resulted in increasingly insecure and hazardous conditions for students. ${ }^{61}$ Student protests were dealt with by force and the National Association of Nigerian Students which had organized the protests against these conditions was split by factionalism encouraged by the government.

New confraternities stepped into this breach while their established predecessors disbanded. ${ }^{62}$ From this point onwards the status of confraternities began to be questioned by the military regime as a site of insurrection. A proliferation of varsity cults emerged in Edo State, including the Buccaneers, Black Axe, Supreme Vikings, Hooded Scorpions, and Eiyo each of which utilized an idiom of secrecy as the basis for organisation. Membership of many of these confraternities is modelled on initiation rites with the use of protective medicines made up from leaves and other substances, invoking the knowledge of the 'native doctors' and shrines. These voluntary associations cross-cut identities based on the politics of ethnicity as perpetuated in differentiated access to tertiary education by federal state allocation and provide a collective solidarity and security for members. ${ }^{63}$ Prominent confraternities are male dominated and have a reputation for toughness accentuated by their initiations and pledges of secrecy. They act to protect members interests whether against other students or individuals within the university hierarchy. They have been active in challenging the 'corruptness' of student representation bodies, lecturers and other university malpractices.

This trajectory and the localized pattern of grievances they articulate is obscured,

60. Both shrines and Pentecostal churches in fact share many common assumptions about witchcraft and both seek to provide protection against witchcraft attacks.

61. Said Adejumobi 'Structural Adjustment, Students' Movement and Popular Struggles in Nigeria, 19861996', in Attahiru Jega (ed.), Identity Transformation and Identity Politics under Structural Adjustment in Nigeria, (Nordiska Afrikainstitutet in collaboration with the Centre for Research and Documentation, Kano, Uppsala, 2000).

62. The Pyrates formally ceased all student campus activities in 1987.

63. JAMB scores in different states require different scores in order to progress to tertiary education, providing this differentiated access according to federal state. 
however, in the widespread discourse on the demonization and criminalization of varsity cults which focuses on the vendetta attacks, ritual killings and their supposed association with armed robbery. ${ }^{64}$ In this context potential sites of resistance to the political regime and to patrimonial power have been framed in terms of a discourse on secret cults which transgress the norms of Nigerian society in ways which reflect the trajectory of a moral panic. ${ }^{65}$ It is significant to remember here that those claiming the academic authority of detached sociological analysis of the varsity cult phenomenon and who situate them beyond the campus and as a challenge to the nation-state are precisely those lecturers and administrators challenged by the cultists. The actions of secret cults, threats of murder or extortion for withholding of grades and payment for lecture handouts are likely to appear petty and irrational ransoms outside the specific context in which they are made. Yet it was for precisely these practices that 120 lecturers at Edo State University (Abraka campus) were sacked in April 2002. ${ }^{66}$ It is of no surprise then that the academic and popular discourse on varsity cults has been robust, and two further and related points emerge from it. Firstly that cult members are often thought to be the sons of senior military and political figures - their initiation being a precursor to their recruitment into the secret echelons of state power hedged in by membership of other secret societies such as the Reformed Ogboni Fraternity. ${ }^{67}$ And secondly, that the violence of the varsity cults is an inflection of and training for the militarized power, the 'culture of violence', which shapes everyday life in contemporary Nigeria.

In contesting and holding to account the authority of patrimonialism within educational institutions through covert and sometimes violent means, these confraternities occupy a contested space. Varsity cults contest modes of university (mis-)administration and hence express a counter-narrative to top-down hierarchies of governance. The ambivalence of their actions engenders their criminalisation within a discourse of secret cults by nonmembers and state institutions. Accountability after all is a situated and positional issue. It is the very idiom of secrecy in which they operate that provides security for the members and enables them to hold others to account, though it is precisely their lack of visibility which allows them to be appropriated to instrumental and criminal means. Hence the varsity cults tie in with everyday discourses on access to resources and the inequity of the distribution of power and knowledge which are a given of patron-client relations.

\section{Conclusion}

While the collective responses to political and economic disorder in Nigeria have been delineated in the preceding sections, in practice they coalesce as configurations which privilege particular rhetorical discourses. The case of the Ibom Allied Congress, an umbrella youth association within Akwa Ibom State serves to demonstrate the interrelatedness of the four types of insurgent engagement with the public sphere we have outlined. As 'sons of the soil' they assert their right to be accommodated, they operate as covert vigilantes, and they employ long standing spiritual traditions of violence in the rhetoric of accountability in the most significant current discourse in the Nigerian political

64. Edo State passed the Secret Cult Prohibition bill in 2000 in which secret cult members from any educational institution or public service upon conviction would be liable to 21 years imprisonment (Nigerian Observer, 7 December 2000).

65 . S. Cohen, Folk Devils and Moral Panics (Paladin, London, 1973).

66. Guardian, 27 April 2002.

67. M. L. Bastian 'Vulture Men, Campus Cultists and Teenaged Witches', in Henrietta L. Moore and Todd Sanders (eds.), Magical Interpretations, Material Realities: Modernity, Witchcraft and the Occult in Postcolonial Africa, (Routledge, London, 2001). 
economy - resource control. The association is a product of its time, it was formed in 2001 'to cleanse the state of anti social ills' ${ }^{68}$ by a former chair to the Akwa Ibom State Monitoring Committee on Petroleum Products and chair of the state chapter of the Civil Liberties Organisation. The Ibom Allied Congress is an umbrella body of 14 'sociocultural' associations from around Akwa Ibom State. At its inaugural meeting the group's chairman said, 'We hereby admonish all contractors handling roads and renovation of schools and hospitals in the state to sit up and execute their jobs satisfactorily as any abandonment of such contracts will be visited with the full wrath of the Ibom Allied Congress.' ${ }^{6} 9$

We are not the CIA,' said its chairman, 'more like the FBI'. The Ibom Allied Congress, is a self-styled security outfit, securing the property, rights and resources of Akwa Ibom state. It engages in covert vigilantism, in identifying criminals for the Police and the State Security Service. Two tactics are employed, the group drinks late at night in Uyo, the state capital and waits for armed robbers especially 'the insider' (owo mbia) to relax and boast of their raids, and they may also employ ('sponsor') girls from the university of Uyo to seduce suspects and record information on hidden 'micro-tapes' (dictation machines).

During 2001 the group, like many other associations and political figures in the state engaged with the 'resource control' question, and challenged the state's major oil production company based at Eket, Exxon/Mobil, to undo its legacy of 'economic sabotage' and to invest more in the state by relocating its headquarters, patronizing local banks and insurance companies, and by employing local professionals and contractors. ${ }^{70}$ Following a public rally and the passing of an ultimatum to accede to local demands, the Ibom Allied Congress led a raid on the company's operational headquarters in Eket and forced them to cease their production for two weeks in June-July $2001 .^{71}$

The aesthetics of the violence demonstrated in the raid are of note since they indicate the articulation of local idioms of protest to a regional political discourse. Prior to the raid members of the youth group followed abstentions from sex and ritual pollution before invoking at its shrine in the forest, the spirit of 'ekpe ikpa ukot' (the leopard who walks in shoes'). The spirit summons up a potentially lethal figure of a man dressed in shorts and wearing rain boots. The spirit was 'hired' from Itu, in the north east of the state, and its links with the theriomorphic 'man-leopard' cults have clearly undergone revision as the man-leopard (ekpe-owo) has a singular resonance for Ibibio speakers following a series of murders in the south-western Annang region were attributed to ekpe owo in the mid1940s. ${ }^{72}$

68. Vanguard, 24 January 2001.

69. Ibid.

70. Other groups involved in this campaign included the 'Ibibio Elders Forum', Akwa Ibom Progressive Congress, the Federation of Etinan youths, the Niger-Delta Youth Movement, and Youths for Victor Attah. Their protests were sparked ostensibly by the appointment of a non-indigene as legal counsel and member of the board of directors of the multinational.

71. Following the incident the managing director of Exxon/Mobil was called to answer questions by the Akwa Ibom State House of Assembly - specifically he was requested to relocate Exxon/Mobil's headquarters from Lagos to Akwa Ibom, to pay VAT to Akwa Ibom State instead of Lagos State, and to justify the appointment of directors from outside Akwa Ibom (Vanguard, 5 July 2001).

72. The invocation of ekpe-owo in this context demonstrates the legal ambiguity of the mode of secrecy. A commonly held conception of trajectories of Annang criminal organizations is that 'before amauke was ekpeowo', before the armed robbers was the man-leopard. Both threatened security, both were organised as criminal gangs, both operated within the idiom of the secret societies and both were linked by belief in the powers of the leopard changing charm. See Geoffrey Nwaka, 'The 'Leopard' Killings of Southern Anang, Nigeria, 1943- 
Links between shape-shifting, secret societies and contemporary conflict in West Africa, notably in Sierra Leone and Liberia, are discussed in recent literature. ${ }^{73}$ Within these trajectories of terror, secret societies are rich repositories of idioms of youth initiation, modes of collective covert action, and of the aesthetics of violence. Within a kinship mode of organization these 'sodalities of initiates' represent countervailing centres of power which echo the shadow structures (cf. the Kaduna Mafia) through which national political power is exercised. ${ }^{74}$ In current writings on the African state which point to the way in which symbolic and cultural idioms are employed to legitimize illicit activities, it is evident that the same cultural repertoires may also be used in response to criminalisation and disorder. ${ }^{75}$ It is in this context that we must understand collective youth responses to disorder not as 're-traditionalization' but within trajectories of routine. When disorder, decenteredness and de-coupling emerges by social change and illegitimacy those who move into action grasp the importance of how cultural patterns are articulated to systems of political domination. Hence, those stepping into the void to re-establish order do so by the knowledge and practice of routine. ${ }^{76}$

Militant youth organisations, Area Boys, vigilantes and secret cults have each emerged from or were transformed by the post-SAP economic crisis. From the mid-1980s, and especially during the coercive and repressive military regimes of the 1990s, covert and secret forms of organization became especially salient to the practices of everyday life. As a basis for access to resources and the distribution of power these modes of collective youth action are generated at the intersecting and interfacing of top-down modes of governance and bottom-up responses to disorder. The localized idioms of accountability expressed by these organizations are realized in discourses on corruption, the contestation of economic and judicial rights, and counter-movements against marginalization and coercion.

Rather than rendering such responses redundant through the economic and political reforms of liberal democracy, the return to civilian rule in Nigeria since 1999 has rather proved to be a source of oxygen to these ambiguously sited 'shadow' structures. The incentives to representation within the new democratic order have been ratcheted-up by renegotiations at the state and regional level of the religious and economic constitution of the Nigerian nation-state. As perceptions of inequality have increased, and the space for their critical discussion has expanded, so localized responses to inequity have been appropriated both at and between federal state and regional levels. These micro-political activities and 'invisible governances ${ }^{177}$ might undermine the social cohesion necessary for the creation of meaningful institutions. Yet they point to the creative potential of youth in southern Nigeria in not only surviving but in reinventing and restructuring disorder.

48' Africa 56, (1986); David Pratten, The Man-Leopard Murder Mysteries: Power and Politics in Colonial Nigeria (forthcoming).

73. Stephen Ellis, The Mask of Anarchy: The Destruction of Liberia and the Religious Dimension of an African Civil War (Hurst and Company, London, 1999); Paul Richards, Fighting for the Rainforest: War, Youth and Resources in Sierra Leone, ed. Alex de Waal and Stephen Ellis, African Issues (James Currey for the International African Institute, London, 1996).

74. Bayart 'The 'Social Capital' of the Felonious State', in, p. 40.

75. Sten Hagberg, 'Enough Is Enough' : An Ethnography of the Struggle against Impunity in Burkina Faso' Journal of Modern African Studies 40, (2002), p. 218.

76. Karen Fields, 'Political Contingencies of Witchcraft in Colonial Central Africa: Culture and the State in Marxist Theory' Canadian Journal of African Studies 16, (1982), p. 593.

77. David Hecht and Maliqualim Simone, Invisible Governance: The Art of African Micropolitics (Autonomedia, New York, 1994). 
This document was created with Win2PDF available at http://www.daneprairie.com. The unregistered version of Win2PDF is for evaluation or non-commercial use only. 